\title{
INTELLECTUAL PATHS AND PATHOLOGIES: HOW SMALL EVENTS IN SCHOLARLY LIFE ACCIDENTALLY GROW BIG
}

\author{
ALTUG YALCINTAS*
}

\author{
Primary Supervisor: Arjo Klamer \\ Institute, University: Erasmus Institute for Philosophy and Economics, \\ Erasmus University Rotterdam \\ Date of Graduation: November 2009 \\ Language: English
}

How do ideas actually evolve? Often, there is more than one pathway of advancement in which different ideas emerge and flow in different directions. Does this mean there is no advancement in intellectual history? Or, are pathways constituents of scholarship?

This thesis argues that it is possible to understand the course of history as overlapping, divergent, and endlessly changing pathways. Such pathways operate in different fashions. They sometimes lead to more coherent and higher levels of understanding, and sometimes they delay or obstruct advancement in intellectual history. In either way, outcomes are unpredictable and multi-directional.

Tangled pathways of intellectual history emerge as consequences of small, seemingly unimportant events of the past. Economists have pointed out a specific group of events that dramatically change the course of history in exceptional ways. Such events hardly fit the general picture drawn by conventional historians. Their consequences accumulate in noticeably different fashions. They are casual events of history that have causal significance for today. Following the writings of Brian Arthur on complexity, increasing returns, and path dependence, such events are called "historical small events." According to Arthur (1989), historical small events are "those events or conditions that are outside the ex-ante knowledge of the observer-beyond the resolving power of his 'model' or abstraction of the situation. ... [T] he small events ... determine ... the path of market shares; the process is nonergodic or path dependent-it is determined by its small-event history." The thesis focuses on this explanation and applies it to the workings of scholarly life to explain a phenomenon that is not rare or ignorable in the intellectual history of economics. The central theme in this work is a discussion of historical small events and the ways in which they accidentally grow big and generate substantial consequences for scholars in the academia and for intellectuals in general.

\footnotetext{
*Research Fellow, Department of Economics, Ankara University, email: altug.yalcintas@politics.
} ankara.edu.tr 
The effects of historical small events multiply in unforeseen and unexpected ways-especially when neglected or overlooked in scientific experiments. Such events are sometimes the errors that researchers overlook. The history of economic ideas is full of errors. These errors are among the factors that generate intellectual pathways in which consequences of historical small events feed back on each other positively and give rise to historical pathologies in the end. The economic literature is often held dependent upon such pathways.

Pathologies in the history of medicine and psychology often show us the central role of historical small events, usually in the form of errors and contradictions, in the making of social and economic institutions: initial conditions (errors), self-reinforcing, often turn into bigger occurrences (pathologies). An error is considered to be any factor that generates formal flaws featuring hereditary interruptions and suspensions in social processes (Canguilhem 1991, p. 278). Under such conditions, harm can be truly large and radical. Errors transform into pathologies within the relation between the organism and its environment. An error is now not defined as a simplistic phenomenon, taking place only once, with predictable results. Instead, it is considered to feature complexity in the sense that linear causal relations lead the system into non-linear states generating substantial outcomes randomly.

The thesis applies this perspective of "intellectual path dependence" on the Coase Theorem. The history of the Coase Theorem requires historians of scholarly economics to pay special attention to historical small events. The controversy over the Coase Theorem is that in a number of important articles and books, that of Stigler (1966) being the first, the Coase Theorem has been analyzed as if Coase argued that the world in which we lived was a world of zero transaction costs. This theorem, however, was not a proper formulation of Coase's message.

Some ideas in history exist in such institutionalized environments that we cannot easily eliminate their consequences: consequences linger and they give rise to further, sometimes erroneous, ideas. The course of events feeds itself in such a way that early events in the course generate intellectual paths that last into the future. Had such ideas not been invented or argued for initially, the entire history of ideas would have been completely different. The case of the Coase Theorem is an example of the development of intellectual paths in the history of economic ideas in which a unique event-i.e., Stigler's misreading (or manipulation) of the writings of Coase-generates an unusual pathway in the evolution of economic thought, a pathway in which the message of the idea was dissimilar to Coase's argument in the 1960s, and onwards. A chance element - namely, Stigler's reading - that was in no way part of Coase's intellectual contribution influenced the way his contribution is construed by economists today.

\section{REFERENCES}

Arthur, B. 1989. "Competing Technologies, Increasing Returns and Lock-in by Historical Events." Economic Journal 99: 116-131.

Coase, R. 1960. "The Problem of Social Cost." Journal of Law and Economics 3: 1-44.

Canguilhem, G. 1991. The Normal and the Pathological. New York: Zone Books.

Stigler, G. J. 1952 [1966]. The Theory of Price. Third edition. New York: The Macmillan Co. 